\title{
MARKET ORIENTASION EFFECT ON THE PERFORMANCE OF THE PRODUCT PROCESSED FISH MARKETING SMES IN JAMBI
}

\author{
Agesha Marsyaf ${ }^{1)}$, Ade Octavia $^{2)}$, Erida $^{3)}$ \\ ${ }^{1)}$ Management Departement, Universitas Muhammadyah, Jambi, Indonesia \\ ${ }^{2,3)}$ Management Department Faculty of Economics and Business, Universitas Jambi, Jambi, Indonesia \\ Corresponding author:agesha.marsyaf.am@gmail.com
}

\begin{abstract}
The address of this research is to analyze the effect of market orientation toward. the performance of Micro, Small and Medium entreprises in the field of Fish processing Products in Jambi City, either simultaniously or partially. The sample of this research are represented by 45 MSME's. This study utilized linear regression analysis. Data of this research was tabulated from respondent responsiveness. The results of this study prove that simultaneously the performance of Micro, Small and Medium entreprises is significant influenced by the market orientation. Furthermore, partially the results show that the customer orientation and competitor orientation have a significant effect toward the performance of MSME. On the other hand, the coordination of inter-function has not significant effect partially toward the performance of MSME. The study suggests for the entrepreneur of Micro, Small and Medium entreprises to improve the function of their internal coordination and give a wider delegation to their employers to do their task.
\end{abstract}

Keywords: Market orientation, customer, competitor, coordination of intern-function, the performance of Micro, Small and Medium entreprises .

\section{Introduction}

Indonesia is one of the founders of the Association of South Asian Nations (ASEAN). ASEAN was formed with the intent and purpose of the interests of member countries in cooperation between fields. One of the ASEAN declaration items contained in www.asean.org is to accelerate the economic growth, social progress and cultural development in the region through joint endeavors in the spirit of equality and partnership in order to strengthen the foundation for a prosperous and peaceful community of South-East Asian Nations. (to accelerate economic growth, social progress and cultural development in the region (ASEAN) through joint efforts in the spirit of equality and togetherness in strengthening the foundation for the welfare and peace of countries in the Southeast Asian region).

With the integration of the economy of a country in the era of free trade, the existence of Micro, Small and Medium Enterprises (MSMEs) in Indonesia can also be expected to become one of the important business actors in the welfare of society. To carry out this role, UKMM Indonesia must have its global competitiveness. According to Tulus Tambunan (2013) international trade liberalization which increases international competition in the domestic market will have an adverse effect on inefficient or low-power MSMEs, while it will benefit MSMEs that are efficient and highly competitive.

According to the Central Statistics Agency (BPS), the development of the number of MSMEs in 2012 was $56,534,592$ and this grew by $2.41 \%$ compared to 2011 as many as 55,206,444 MSMEs in Indonesia. MSMEs absorbed $107,657,509$ workers or grew by $5.83 \%$ compared to 2011 as many as $101,722,458$.

Jambi Province with Jambi sea area $+44,496 \mathrm{Km} 2$ with beach length $+210 \mathrm{Km}$, has the potential of capture fisheries contained in it around 71,820 tons / year, consisting of types of economically important fish such as catfish, mackerel fish, Bawal, Senangin, Bloated, Cracked Shrimp and various other types of shrimp, etc. (Source: Jambi Province Marine and Fisheries Service, 2014).

Based on a variety of fisheries products, according to the Jambi Province Marine and Fisheries Service source (April 30, 2015), Jambi Province has 24 types of fisheries products processed by micro, small and medium enterprises (MSMEs).

The largest amount of production for processed products made from non-catfish raw materials is foreign fish as many as 1,007,004 per year, the second largest typical product of Jambi, which is Tekwan as many as 678,648 per year and the three Pempek processed products are 457,788 per year. While for the processed products which are made of raw catfish, the largest are catfish crackers as many as 731,064 per year, the position of the two fish salai is $46,356 \mathrm{~kg}$ per year and the third is catfish abon as much as 14,748 per year. 
The problems faced by MSMEs in Jambi City have an impact on marketing performance that is not optimal. The above problems are estimated because of the factor of being unable to develop their business by referring to market-oriented businesses, improving quality, productivity and competitiveness by utilizing existing resources and always following developments in information and technology. According to Narver and Slater (1990) the company's ability to understand the wants and needs of consumers and provide products or services desired and needed by consumers is known as market orientation or market orientation.

Narver and Slater (2000) state that market-oriented companies can improve their company performance due to customer-oriented company behavior, competitor orientation and coordination between functions within the company. Likewise, the performance of small companies will increase if market oriented. Market-oriented companies show company behavior that emphasizes strongly on customer needs and satisfaction for the goods or services offered. Then, always monitor the actions of competitors so that they can continue to respond quickly to their competitors' strategies. Finally, the company coordinates market information on functions within the company so that all functions can focus on providing the best customer value.

Octavia (2013) also stated in the results of his research namely Jambi batik entrepreneurs who have an orientation to export marketing to prepare three factors, namely customer-oriented culture, marketing mix strategy and creating competitive advantage. The implication for the government is that it needs strong support from the government to Jambi batik entrepreneurs to be able to improve their marketing performance and penetrate the export market. Such support in the form of concrete actions such as providing information to Jambi batik entrepreneurs about access to foreign markets, documents that must be completed, building networks to facilitate the search for communication and information, providing convenience in licensing and other aspects.

Marketing performance according to Tjiptono et al (2008) marketing performance is an overspent and underdelivered point, because of the difficulty of measuring the effectiveness and efficiency of every activity, decision or marketing program. So that marketing performance is more objective and focused on profitability and productivity of marketing decisions. The success of marketing performance is reflected in the success of its business in the world of business competition. Besides that the measure of the success of marketing performance can also be seen from the level of success of new products that show that the company is performing better.

Based on the description of the research background, it can be concluded that the research question is "Does the Market Orientation Affect Significantly and Partially Significantly on the Marketing Performance of MSMEs in processed fish products in Jambi City"

\section{Research Objectives}

- Analyzing the effect of simultaneous market orientation on the marketing performance of MSMEs in processed fish products in Jambi City

- Analyzing the effect of partial market orientation on the marketing performance of MSME Processed Fish Products in Jambi City

\section{Literature Review}

Kotler in his book Marketing Management Analysis, Planning, and Control, defines marketing more broadly, namely: Marketing is: A social process, where individuals and groups get what they need, and they want by creating and maintaining products and values with individuals and other groups. Marketing Management is one of the main activities carried out by the company to maintain the continuity of the company, develop, and make a profit. The marketing process begins long before goods are produced, and does not end with sales. The company's marketing activities must also give satisfaction to consumers if they want their business to continue, or consumers have a better view of the company. Dharmmesta \& Handoko (1982).

Important Elements in the concept of Market oriented marketing are oriented towards the desires of consumers, then the preparation of integrated marketing activities, as well as the achievement of the level of customer satisfaction, and the Management Concept essentially encompass efforts and strategies pursued by management in order to reach the level of customer satisfaction

\section{Market orientation}

Market orientation (market orientation $=\mathrm{MO}$ ) is a measure of behavior and activity that reflects the implementation of the marketing concept. Ironically, even though the marketing concept has been developed in the 1950s decade, it was only in the 1990s that empirical studies began to be carried out to examine marketing concepts and strategies for business success. The main pioneers are Kohli and Jaworski (1990, 1993) in their article "Market Orientation: The constructs, research propositions, and managerial implications" and "Market orientation: antecedents and consequences" and Narver and Slater (1990) in the article "The effect of market orientation on business profitability ". 


\section{Customer Orientation}

Kotler (2007) states that what the customers want is more important than the products currently sold to customers. Customer orientation is defined as an adequate understanding of the target buyer, so that superior value can be given continuously (Narver \& Slater, (1990). Further explained that customer orientation is defined as an adequate understanding of the target of buying customers with the aim that can create superior value for buyers on an ongoing basis. Understanding here includes understanding of the buyer's entire value chain, both at the moment and at the time of its development in the future.

\section{Competitor orientation}

Competitor orientation can be expressed through monitoring of information about competitors and disseminating such information to all functions within the company such as research and product development divisions or discussing with top management how the competitor's strengths and the strategies they develop, both concerning action present and future actions. Competitive-oriented companies will always use most of their time to track the use of competitors' strategies and market share and try to put forward various strategies to counter them (Zhou et al., 2005).

\section{Marketing Performance}

Marketing performance is a concept to measure the marketing performance of a product. Marketing performance is a construct (factor) that is commonly used to measure the results of all company strategies. Therefore the measure that should be used is a measure that is an activity based measure that can explain the marketing activities that produce the marketing performance. (Ferdinand, 2000)

Marketing performance according to Tjiptono et al (2008) marketing performance is an overspent and underdelivered point, because of the difficulty of measuring the effectiveness and efficiency of every activity, decision or marketing program. So that marketing performance is more objective and focused on profitability and productivity of marketing decisions. The success of marketing performance is reflected in the success of its business in the world of business competition. Besides that the measure of the success of marketing performance can also be seen from the level of success of new products that show that the company is performing better.

\section{Research Methods}

\section{Population and Samples}

The population in this study of business (UMKM) processed fish products in the city of Jambi was recorded as many as 45 MSMEs and 825 types of processed fish products in 2014 (the source of strategic planning for MSMEs in Jambi City.

\section{Data Collection Techniques Interview}

Conducting question and answer directly with business actors (MSMEs) of processed fish products in the city of Jambi, regarding aspects of marketing performance, both from the orientation of competitors, consumers and coordination between functions, other matters relating to this research.

\section{Observation}

Carry out careful and systematic observations on the marketing performance of MSMEs in processed fish products in Jambi province

\section{Questionnaire}

That is how to obtain structured primary data by using a closed list of questions given to respondents.

\section{Research and Measurement Variables}

The dependent variable in this study is the marketing performance of MSMEs (Y), while the independent variables are customer orientation (X1), cruise orientation (X2), coordination between functions (X3), and price discounts (X4). The questionnaire contained questions whose measurements used a 1-5 Likert scale. For each indicator the respondent gave his assessment. Furthermore, data analysis using quantitative analysis using the moderating regression analysis formula.

\section{Results and Discussion \\ Research Results}

Respondents who were sampled in this study were fish processing business actors domiciled in Jambi City. Before the statistical test is carried out, the validity and reliability tests are first carried out. By using SPSS it is known that the five research variables are valid and reliable. 
Thus the data from the field can be continued to the next test, namely the multiple regression test and moderation regression. The results of statistical tests from primary data are presented as follows.

Table 1: Summary of Statistical Test Results Effect of Brand Image, Product Knowledge and Product Quality on Intention to Buy with Price Discounts as Moderator Variables

\begin{tabular}{clcl}
\hline No. & \multicolumn{1}{c}{ Statistics Size } & $\begin{array}{c}\text { Calculating Value and Regression } \\
\text { Coefficient }\end{array}$ & \multicolumn{1}{c}{$P_{\text {value }}$} \\
\hline 1. & Uji F & 124,800 & $0,000^{* *}$ \\
& Uji t & & $0,000^{* *}$ \\
& • Customer Orientation $\left(\mathrm{X}_{1}\right)$ & 0,331 & 0,646 \\
& • Competitor Orientation $\left(\mathrm{X}_{2}\right)$ & 0,419 & $0,002^{* *}$ \\
\hline & • Coordination between functions $\left(\mathrm{X}_{3}\right)$ & 0,142 & \\
\hline 2. & Coefficient of Determination $R^{2}$ & 0,635 & \\
\hline
\end{tabular}

Source: Processed primary data with SPSS, 2016

Description: ** highly significant

The regression models in this study are as follows:

$$
\mathrm{Y}=1.118+0.522+0.048+0.255+\mathrm{e}
$$

The test results show that simultaneously the $\mathrm{F}$ value is 124,800 percent. Statistically it is highly significant. While the partial test shows that the relationship of the three variables is positive, with a highly significant value on the market orientation variable and customer orientation, while the coordination between functions is not significant.

\section{Discussion \\ Customer orientation}

The results of this study indicate that if the customer orientation is at a high level, it will improve the performance of MSMEs. In other words, high customer orientation will affect the improvement in the performance of MSMEs. If the respondent has a lot of information about the customer, it will be able to meet the needs according to customer needs, which in turn will improve the performance of MSMEs.

Based on the results of research conducted by Lin and Lin (2007) which states that customer orientation has a positive influence. Consumers hope to get more information about the product as best they can before making a purchase. Product knowledge in consumers illustrates the ability of consumers to meet every product need with a particular brand they need.

\section{Competitor orientation}

Based on the results of research by Narver and Slater (2000) Market-oriented companies show the behavior of companies that emphasize strongly on the needs and satisfaction of customers for the goods or services offered. Then, always monitor the actions of competitors so that they can continue to respond quickly to their competitors' strategies. Finally, the company coordinates market information on functions within the company so that all functions can focus on providing the best customer value.

\section{Inter-Functional Coordination}

This indicates that if coordination between functions is at a high level, it will improve the performance of MSMEs not significantly. In other words, high coordination between functions will affect the performance of MSMEs. If the respondent has high coordination with his subordinates, it will create good communication which will ultimately improve the performance of MSMEs.

Based on the results of the research conducted by Perengki Susanto (2012), this finding provides a clear indication that the difference between market orientation in large and small companies can be seen from the dimensions of coordination between functions that have no significant effect on the performance of small companies. This reflects the actual behavior of small companies in Yogyakarta as illustrated by the results of their answers to questions related to coordination between functions whose average value is in the low category. This indicates that the absence of a clear division of tasks between the owner or company manager and employees or other company functions such as marketing functions and production functions is also carried out by company managers.

\section{Conclusions and Recommendations}

Based on the results of the analysis and discussion described earlier, some conclusions can be drawn from the overall results of the study as follows: Customer orientation variables have a positive and significant effect on the performance of MSMEs; Competitive orientation variables have a positive and 
significant effect on the performance of MSMEs; The coordination variable between functions does not have a significant effect on the performance of MSMEs.

Suggestions that can be given from the research results are as follows: MSMEs not only focus on competitors but also on customers and market segments where later the MSME products will be marketed so that in the future the performance of MSMEs will be more optimally developed. MSME actors are advised to improve coordination between functions and need to delegate marketing tasks to staff employees. Future research should be carried out on the broader object of research not only limited to MSMEs of processed fish products in the city of Jambi alone but more broadly including fish-processed MSMEs in Jambi Province.The existence of other factors of $36.5 \%$ affects the performance of MSMEs, so future research should add other influential variables, which can be included in future studies. There are several indicators or variables not included in this study, which can be included in further research such as product innovation by increasing innovation in packaging to attract consumers, innovation in sales promotion, for example not only direct marketing but also online which affects marketing performance UMKM so that in the future it will be better, so that the inclusion of many variables in this study will get more valid results.

\section{References}

Adinoto.,(2013), Pengaruh Orientasi Pasar dan Perilaku Kewirausahaan Terhadap Kepekaan Perusahaan Dan Implikasinya Pada Kinerja Perusahaan: Studi pada Penyalur Sepeda Motor di Indonesia, Ultima Management, Vol 4, No. 10.

Alam, M.M., (2013), Effect of Market Orientation on Small Business Perormance in Small Town In Malaysia: An Emprical Study on Malaysian Small Firms, Journal of Strategic Marketing, Vol 1, No. 3

Bhuian, S.N., Menguc, B., \& Bell, S.J. (2005). Just entrepreneurial enough: The moderating effect of entrepreneurship on the relationship between market orientation and performance. Journal of Business Research, 58: 9-17.

Chen, M., \& Hambrick, D. C. (1995). Speed, stealth and selective attack: How small firms differ from large firms in competitive behavior. Academy of Management Journal, 38(2): 453-482.

Deshpande, R., \& Farley, J. (1999). Corporate culture, custome orientation,and innovativeness in Japanese firms. Journal of International Marketing, 57 (1): 23-38.

Forbes, D.P. (2005). Managerial determinants of decision speed in new ventures. Stategic Management Journal, 26 (9): 355-366.

Hult, G. T., Ketchen, Jr., David J., \& Slater, S.F. (2005). Market Orientation and Performance: An Integration of Disparate Approaches. Strategic Management Journal, 26 (12): 1173-1181.

Jaworski, B.J., \& Kohli, A.K. (1993). Market Orientation: Antecedents and consequences. Journal of Marketing, 52 (7): 53-70.

Jaworski, B.J., \& Kohli, A. (1996). Market Orientation: Review, refinement, and roadmap. Journal of Market Focused Management, 1 (2): 119-35.

Kotler, P. dan Keller, K. (2000), Marketing Management, Millennium Edition, 12c, Prentice Hall, Inc.

Kotler, P. (2000). Marketing Management. NJ; Prentice Hall.

Kara, A., Spillan, J. E., \& Deshields, O. W. (2005). The Effect of a Market Orientation on Business Performance: A Study of Small-Sized Service Retailers Using Markor Scale. Journal of Small Business Management,43(2): 105-118.

Lie, Y., Zhao, Y., Tan., J., \& Liu, Y. (2008). Moderating effects of entrepreneurial orientation on market orientation-performance linkage: Evidence from Chinese Small Firms. Journal of Small Business Management, 46 (1): 113-133.

Narver, J. and Slater, S. (1990). The effect of a market orientation on business profitability. Journal of Marketing, 54 (10): 20-35.

Noble, C.H., Sinha, R.K., \& Kumar, A. (2002). Market orientation and alternative strategic orientations: A longitudinal assessment of performance implications. Journal of Marketing, 66 (4): 25-39.

Octavia, Ade. (2009). “Orientasi Pasar Dan Kualitas Layanan Jasa Rumah Sakit Milik Pemerintah Di Kota Jambi. “Jurnal Penelitian Universitas Jambi Seri Humaniora Vol 11(1).

Octavia, Ade. (2013). " Faktor- faktor pendorong terbentuknya orientasi pasar ekspor batik jambi . "Jurnal Dinamika Manajemen Vol 2(3).

Perengki, Susanto. “ Pengaruh orientasi pasar pada kinerja perusahaan kecil .” Jurnal Kajian Manajemen Bisnis 1 ( 2012).

Slater, S. F., \& Narver, J. C. (1994). Does competitive environment moderate the market orientationperformance relationship?, Journal of Marketing, 58(1): 46-55.

Slater, S. F., \& Narver, J.C. (1995). Market orientation and the learning organization. Journal of Marketing, 59 (7): 63-74.

Slater SF, \& Narver JC. (1998). Customer-led and market-oriented: let's not confuse the two. Strategic Management Journal, 19(10): 1001-1006. 